\title{
Estimation of Peak Flow Rates for Small Drainage Areas
}

\author{
Baoyuan Liu ${ }^{1,2} \cdot$ Daan Wang ${ }^{2} \cdot$ Suhua $\mathrm{Fu}^{2,3}$. \\ Wenhua $\mathrm{Cao}^{4}$
}

Received: 28 August 2016 / Accepted: 21 February 2017 /

Published online: 9 March 2017

(C) The Author(s) 2017. This article is published with open access at Springerlink.com

\begin{abstract}
Runoff plots are important for soil loss measurements, and increasing numbers of plots use automatic equipment. To choose equipment with appropriate capacities, the peak flow rate must be known. The peak flow rate is also an important parameter in the modified universal soil loss equation (MUSLE) which calculate the soil loss from upland slope. The available peak flow rate equations are primarily for the watershed scale, not for small drainage areas like runoff plot. This study's purpose was to derive an equation suitable for the small drainage areas. A total of 149 runoff events on 5 runoff plots were used to develop a peak flow rate equation for the hillslope scale. All plots are located in the Tuanshangou catchment, Zizhou county, Shaanxi province, China. Dimensionless analyses were used to determine the equation form of linear regression analyses. The results revealed that the peak flow rate was significantly correlated with plot area, slope steepness, runoff depth, rainfall depth and the maximum 30-min rainfall intensity. Two equations were developed to estimate peak flow. The model efficiencies of both equations exceeded 0.9. The equations developed in this study
\end{abstract}

Suhua Fu

suhua@bnu.edu.cn

Baoyuan Liu

baoyuan@bnu.edu.cn

Daan Wang

daan_wang@mail.bnu.edu.cn

Wenhua Cao

99341696@qq.com

1 State Key Laboratory of Soil Erosion and Dryland Farming on the Loess Plateau, Northwest A\&F University, Yangling 712100, People's Republic of China

2 Faculty of Geographical Science, Beijing Normal University, Beijing 100875, People's Republic of China

3 State Key Laboratory of Soil Erosion and Dryland Farming on the Loess Plateau, Chinese Academy of Sciences and Ministry of Water Resources, Yangling 712100, People's Republic of China

4 The Monitoring Center of Soil and Water Conservation, Ministry of Water Resources, Beijing 100053, People's Republic of China 
represent an important complement to existing peak flow rate equations. These new equations will facilitate the design of soil conservation practices and/or the selection of flow-observation equipment for small drainage areas.

Keywords Runoff plots $\cdot$ Peak flow $\cdot$ Runoff $\cdot$ soil conservation practices

\section{Introduction}

Runoff plots have been an important means to monitor runoff and soil loss since their development by the German scientist Wollny in 1882 (Baver 1938). Peak flow is a key parameter when selecting the size of the trough connecting a runoff plot and a collecting tank and/or the size of the H-flume or other equipment used to measure the flow discharge of runoff plots. On the other hand, the design of soil-conservation measures, including terraces, fishscale ditches and road or highway gutters, also requires knowledge of the peak flow from small drainage areas. In addition, peak flow rate is an important parameter in the modified universal soil loss equation (MUSLE) (Williams 1975) which to calculate the soil loss from upland slope. The MUSLE is also a significant part in soil and water assessment tool (SWAT) (Neitsch et al. 2005) which has been widely used all over the world. Thus, the precise prediction of peak flow is important when small drainage areas are involved.

In 1851, Mulvaney presented the Rational Formula (eq. (1)), which may have been the first equation for predicting peak flow (Chow 1964):

$$
Q_{p}=\frac{C I A}{360}
$$

where $Q_{\mathrm{p}}$ is the peak flow $\left(\mathrm{m}^{3} \mathrm{~s}^{-1}\right), C$ is a runoff coefficient, $I$ is the rainfall intensity at the time of concentration $(\mathrm{mm} / \mathrm{h})$, and $A$ is the drainage area (ha). O'Connell (1868) linked peak discharge to drainage area and proposed the following power law formula:

$$
Q_{\mathrm{p}}=\mathrm{a} A^{0.5}
$$

where $a$ is a coefficient related to the region. Creager et al. (1944) concluded that the exponent of $A$ was not constant and instead decreased as the drainage area increased. They proposed the following formula:

$$
Q_{\mathrm{p}}=46 C A^{0.894 A^{-0.048}}
$$

Where $C=200$. Then, in the early 1960s, the United States Geological Survey (USGS) adopted the form of eq. (2) and rewrote it as eq. (4) to predict peak flow for a given return period (Ayalew et al. 2014):

$$
Q_{p}=\alpha A^{\theta}
$$

where $\alpha$ and $\theta$ are functions of a return period. The value of exponent $\theta$ is dependent on the watershed scale. Subsequently, many studies were performed to determine the value of $\theta$. The $\theta$ value obtained by Benson (1962) was 0.85 for a return period of 2.33 yr. at 164 watersheds $\left(2.5-26,000 \mathrm{~km}^{2}\right)$ in the humid New England region. Later, Benson (1964) used data from semi-arid regions of Texas and New Mexico and found that $\theta$ was 0.59 for a return period of 2.33 yr. at 219 watersheds $\left(2.5-91,000 \mathrm{~km}^{2}\right)$. Alexander (1972) obtained an average estimate 
of 0.7 for $\theta$ using data from U.S. and British catchments with drainage areas that varied from $130 \mathrm{~km}^{2}$ to $5200 \mathrm{~km}^{2}$. Murphey et al. (1977) found a mean $\theta$ value of 0.62 using data from 149 events and 11 watersheds in Walnut Gulch, Arizona, U.S. Goodrich et al. (1997) also used data collected in the Walnut Gulch watershed and found that $\theta$ was 0.85 for 2-yr. return periods and drainage areas less than $1 \mathrm{~km}^{2}$ but 0.55 for 2 -yr. return periods and drainage areas exceeding $1 \mathrm{~km}^{2}$. Ogden and Dawdy (2003) analyzed peak discharge data from the Goodwin Creek basin, Mississippi, U.S. They examined 16 yr. of continuous rainfall and runoff data for drainage areas ranging from 0.172 to $21.2 \mathrm{~km}^{2}$ and found a $\theta$ value of 0.77 , independent of the return period. Gupta et al. (2007) determined that $\theta$ was 1 for small basins dominated by rainfall-runoff variability and 0.5 for large basins dominated by network structure and flow dynamics. Gupta et al. (2010) used mean annual peak flow data for the Iowa River basin $\left(6.6 \mathrm{~km}^{2}\right.$ to $\left.32,374 \mathrm{~km}^{2}\right)$ and obtained a $\theta$ value of 0.54 . Di Lazzaro and Volpi (2011) determined a $\theta$ value of 0.52 using data for a watershed area located in the Tiber River region, Central Italy, that varied from $218 \mathrm{~km}^{2}$ to $4116 \mathrm{~km}^{2}$.

In addition, several empirical equations were developed. Knisel (1980) derived a peak flow equation that included the variables of drainage area, runoff depth, channel slope and watershed length and width. The exponent of the drainage area was 0.7 for watershed areas ranging from 0.71 to $62.18 \mathrm{~km}^{2}$. Fu et al. (2008) used drainage area, runoff depth and rainfall depth as variables and obtained a drainage area exponent of 0.59 .

Based on these results, we can observe that $\theta$-varies with watershed area. The values of the drainage area exponents in the cited studies are summarized in Table 1, which shows that the exponent of the drainage area decreases generally with increased drainage area, which was in agreement with the results of Creager et al. (1944) and Alexander (1972). The existing peak flow equations are primarily derived from the data on the watershed scale. The smallest drainage area used in the literature is $1830 \mathrm{~m}^{2}$ (Table 1). Little information on the peak flow rate equation is available for the plot scale $\left(40.5 \mathrm{~m}^{2}\right.$ for unit plot which was tipical size for runoff plot) or small drainage area, and no study has investigated whether the peak flow equation developed for the watershed scale is suitable for the plot scale. Therefore, the purpose of this study is to validate the suitability of watershed peak flow equations for the plot scale and to develop a new peak flow rate equation for this scale. This study will provide new knowledge for peak flow in small area, which could be helpful for understanding the mechanism of peak flow generation and development. The new equations also can be used in design of the conservation practices and runoff and soil loss measure devices.

Table 1 Exponent values of the drainage area in the peak flow equations

\begin{tabular}{llll}
\hline Region & Drainage area $\left(\mathrm{km}^{2}\right)$ & Exponent & References \\
\hline Walnut Gulch , AZ,USA & $0.00183-1$ & 0.85 & Goodrich et al. (1997) \\
Goodwin Creek basin , MS,USA & $0.172-21$ & 0.83 & Ogden and Dawdy (2003) \\
USA & $0.71-62$ & 0.70 & Knisel (1980) \\
Chabagou, Zizhou, Shaanxi, China & $0.21-96$ & 0.59 & Fu et al. (2008) \\
Walnut Gulch, AZ,USA & $1-149$ & 0.55 & Goodrich et al. (1997) \\
Texas and New Mexico etc., USA & $2.5-91,000$ & 0.59 & Benson (1964) \\
Iowa river basin, IA.USA & $6.6-32,374$ & 0.54 & Gupta et al. (2010) \\
Tiber River region, Central Italy & $218-4116$ & 0.52 & Di Lazzaro and Volpi (2011) \\
\hline
\end{tabular}




\section{Materials and Methods}

\subsection{Data Sources}

In this study, measured peak flow data for 5 runoff plots and 5 watersheds were used. The runoff plot data were used to develop new peak flow equations for small-scale drainage areas. The data for 5 watersheds were used to validate the existing equations and to determine whether they performed the same or differently on the watershed and plot scales.

The runoff plots are located in the Tuanshangou catchment in the center of the Loess Plateau in Zizhou county, Shaanxi province, China (Fig.1). The plot areas varied from $300 \mathrm{~m}^{2}$ to $17,200 \mathrm{~m}^{2}$ (Table 2). Three plots (Nos. 2, 3 and 4) were regular rectangles with a width of $15 \mathrm{~m}$ and different slope lengths. One plot (No. 7) covered an entire hill slope from the top of the hill to the bottom of the valley. The last plot (No. 9) was a small catchment. The slope steepness of the five plots changed from $40.4 \%$ to $67.5 \%$, and the slope aspect was mainly northeast. The soil type was Cultivated Loessial Soils, which is characterized by a uniform texture and weak structure (Li et al. 2003). The land use of all the plots was cropland, and they were regularly cultivated. The region has a semiarid continental climate with an average annual rainfall of $535 \mathrm{~mm}$. Rainfall events primarily occur from June to September. A total of 149 storm events with runoff depths exceeding $0.1 \mathrm{~mm}$ for the period 1963-1967 were selected. The runoff depth varied from $0.1 \mathrm{~mm}$ to $28.67 \mathrm{~mm}$ (Fig. 2). The runoff duration is generally short and less than 215 min (Table 3). The maximum runoff duration significantly increases as the plot area increases. The measured peak flow rates ranged from $0.2 \mathrm{ls}^{-1}$ to $919 \mathrm{ls}^{-1}$. The magnitude of the peak flow rate varied with the plot area (Fig. 3). The peak flow rates for drainage areas of $0.03,0.06,0.09,0.49$ and 1.72 ha at a cumulative frequency of approximately $50 \%$ (i.e., a 2-yr. return period) were 5, 10, 15, 50 and 100 1/s, respectively. Most runoff hydrographs exhibit one peak value and positive skewness (Fig. 4), indicating that the discharge rises rapidly after the runoff begins and then declines slowly.

The basic watershed information is summarized in Table 4. The watersheds are also located in Zizhou county, Shaanxi province, China (Fig.1). The climates and soil types of the watersheds resemble those of the runoff plots. The measured peak flow rates ranged from $0.002 \mathrm{~m}^{3} \mathrm{~s}^{-1}$ to $1520 \mathrm{~m}^{3} \mathrm{~s}^{-1}$.

\subsection{Procedure}

First, two peak flow rate equations were selected. Eq. (5) was from the Chemicals, Runoff and Erosion from Agricultural Management Systems (CREAMS) model (Knisel 1980), and eq. (6) was from Fu et al. (2008).

$$
Q_{p=3} 3.79 A^{0.7} C S^{0.16}\left(\frac{R}{25.4}\right)^{0.9 A^{0.02}}\left(\frac{L^{2}}{A}\right)^{-0.19}
$$

where $Q_{\mathrm{p}}$ is the peak flow rate $\left(\mathrm{m}^{3} \mathrm{~s}^{-1}\right), A$ is the drainage area $\left(\mathrm{km}^{2}\right), C S$ is the average slope of the main channel $(\mathrm{m} / \mathrm{km}), R$ is the runoff depth $(\mathrm{mm})$, and $L$ is the watershed length $(\mathrm{km})$.

$$
Q_{p}=6.69 A^{0.59} R^{1.15 A^{0.06}} P^{-0.72}
$$

where $P$ is the rainfall amount (mm). 


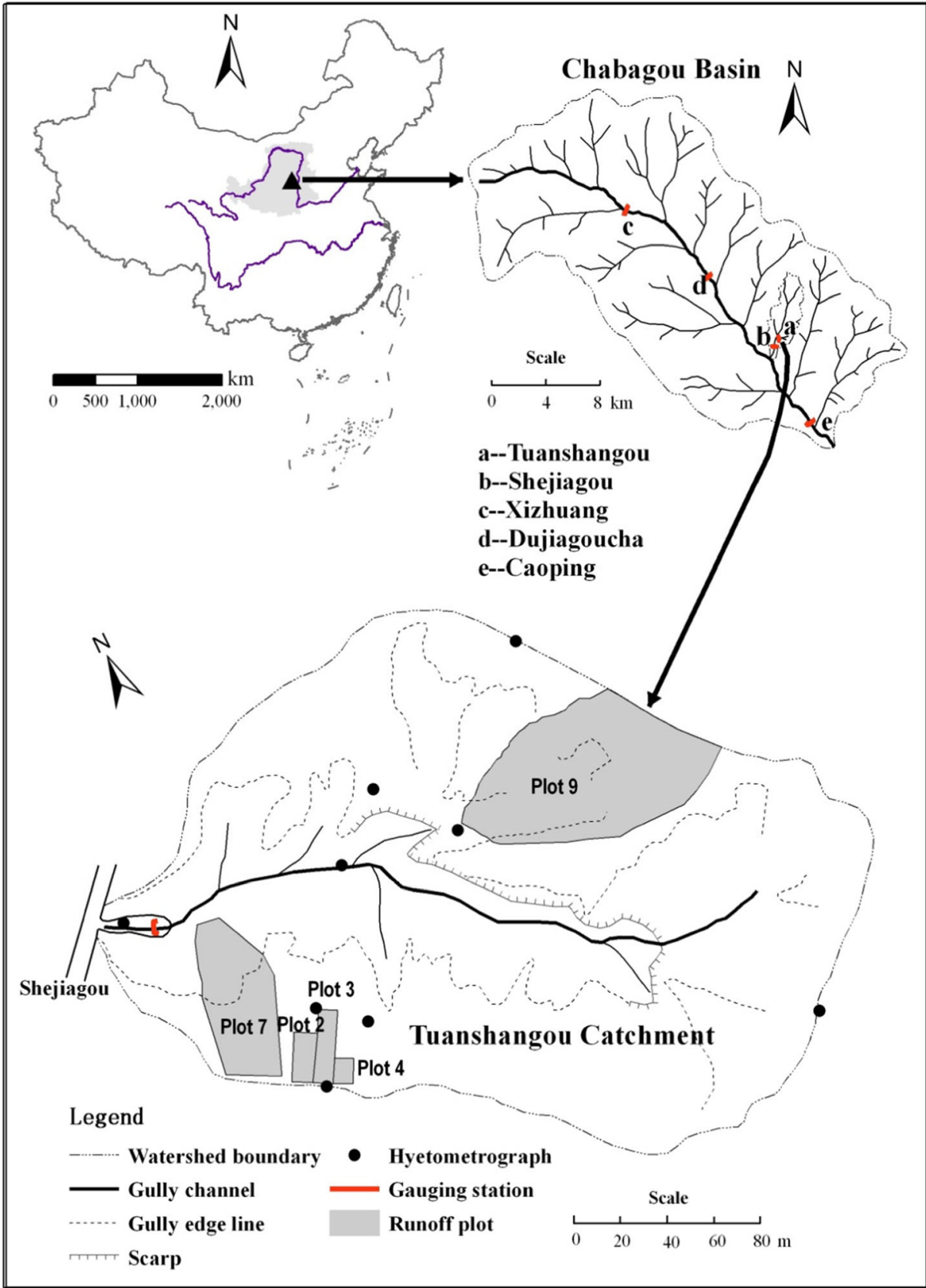

Fig. 1 Location of plots and watersheds used in this study

The primary reason for selecting these equations was that the equations' parameters are straightforward to obtain. In addition, eq. (5) had a similar size scale, and eq. (6) had climate, land use, landform and soil conditions similar to those used in this study. 
Table 2 Runoff plot area and peak flow rate used in this study

\begin{tabular}{lllllllll}
\hline No. & $\begin{array}{l}\text { Length } \\
(\mathrm{m})\end{array}$ & Width $(\mathrm{m})$ & $\begin{array}{l}\text { Area } \\
\left(\mathrm{hm}^{2}\right)\end{array}$ & Slope $(\%)$ & Land Use & $\begin{array}{l}\text { No. of } \\
\text { events }\end{array}$ & $\begin{array}{l}\text { Range of peak } \\
\text { flow }\left(\mathrm{m}^{3} / \mathrm{s}\right)\end{array}$ & $\begin{array}{l}\text { Mean peak } \\
\text { flow }\left(\mathrm{m}^{3} / \mathrm{s}\right)\end{array}$ \\
\hline Plot 4 & 20 & 15 & 0.03 & 40.4 & Cropland & 36 & $0.0002-0.0293$ & 0.005 \\
Plot 2 & 40 & 15 & 0.06 & 40.4 & Cropland & 34 & $0.0004-0.0451$ & 0.012 \\
Plot 3 & 60 & 15 & 0.09 & 40.4 & Cropland & 32 & $0.0003-0.0497$ & 0.015 \\
Plot 7 & 140 & 29 & $0.49^{*}$ & 67.5 & Cropland & 26 & $0.0015-0.2740$ & 0.063 \\
Plot 9 & 161 & 107 & 1.72 & 67.5 & Cropland & 21 & $0.0107-0.9190$ & 0.205 \\
\hline
\end{tabular}

* $0.41 \mathrm{hm}^{2}$ for the year of 1963-1964 and $0.57 \mathrm{hm}^{2}$ for the year of 1965-1967

Second, the Pearson correlation analysis between peak flow rate and effect factors (including plot area, runoff depth, rainfall depth, maximum 30-min rainfall intensity $\left(I_{30}\right)$, plot slope steepness and length-width ratio) was conducted using SPSS 19.0 software.

Third, dimensionless analysis was conducted according to Buckingham's $\pi$ theorem. Then, regression analyses were performed to develop new equations. The runoff plot data were divided into two sets to develop and validate the equations. The first 119 events were used to develop a new equation for the plot peak flow rate. The second 30 events were used to validate the new equation. The second dataset of 30 events was obtained by selecting 1 of every 4 events in chronological order.

Finally, the following criteria were used to evaluate the equations' performance. Model efficiency $(M E)$ (eq.(7)) and mean absolute error $(M A E)$ (eq.(8)) were applied to evaluate the goodness of fit between predicted and measured data.

$$
M E=1-\frac{\sum_{i=1}^{n}\left(Q_{o b s}-Q_{c a l}\right)^{2}}{\sum_{i=1}^{n}\left(Q_{o b s}-\bar{Q}_{o b s}\right)^{2}}
$$
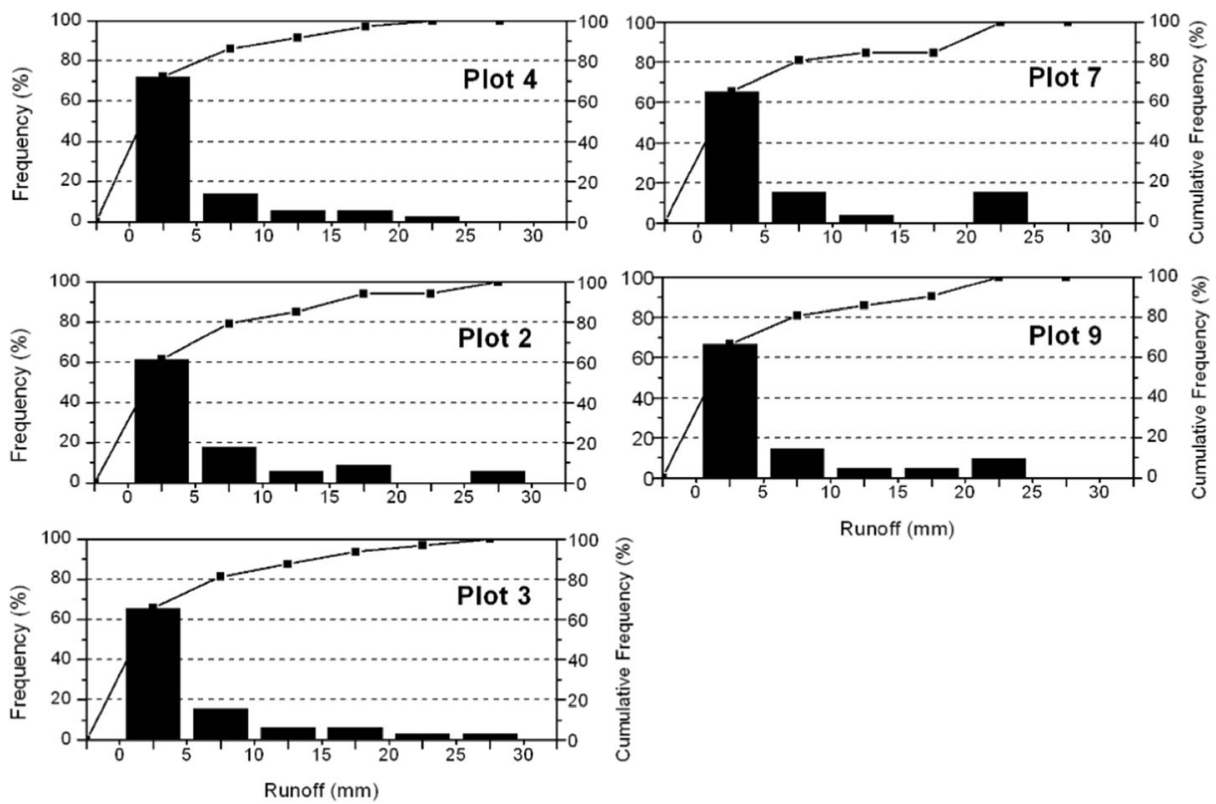

Fig. 2 Histogram and cumulative frequency of the runoff depth 
Table 3 Quantile statistics for runoff duration (min)

\begin{tabular}{llllll}
\hline No. & Min & Q1 & Q2 & Q3 & Max \\
\hline Plot 4 & 6 & 8 & 20 & 28 & 55 \\
Plot 2 & 9 & 14 & 21 & 29 & 56 \\
Plot 3 & 5 & 12 & 21 & 31 & 57 \\
Plot 7 & 9 & 23 & 32 & 41 & 126 \\
Plot 9 & 13 & 31 & 41 & 59 & 215 \\
\hline
\end{tabular}

Q1and Q3 are the 1st and 3rd quartile of the runoff duration. Min, Q2 and Max are the minimum, median and maximum of runoff duration, respectively

$$
M A E=\frac{1}{n} \sum_{1}^{n}\left|Q_{o b s}-Q_{c a l}\right|
$$

where $Q_{o b s}$ is the measured peak flow, $Q_{c a l}$ is the predicted value, $\bar{Q}_{o b s}$ is the mean observed peak flow value, and $\mathrm{n}$ is the number of events.

\section{Results}

\subsection{Validation of the Existing Peak Flow Equations}

The $M E$ of the peak flow eq. (5) in the CREAMS model ranges from 0.55 to 0.78 for different plots and from -0.35 to 0.22 for different watersheds (Table 5). The $M E$ of eq. (5) sharply decreases when the area exceeds 1.72 ha. The $M E$ of eq. (6) from Fu et al. (2008) varies from -4.3 to 0.83 for different plots and from 0.70 to 0.89 for different watersheds and substantially
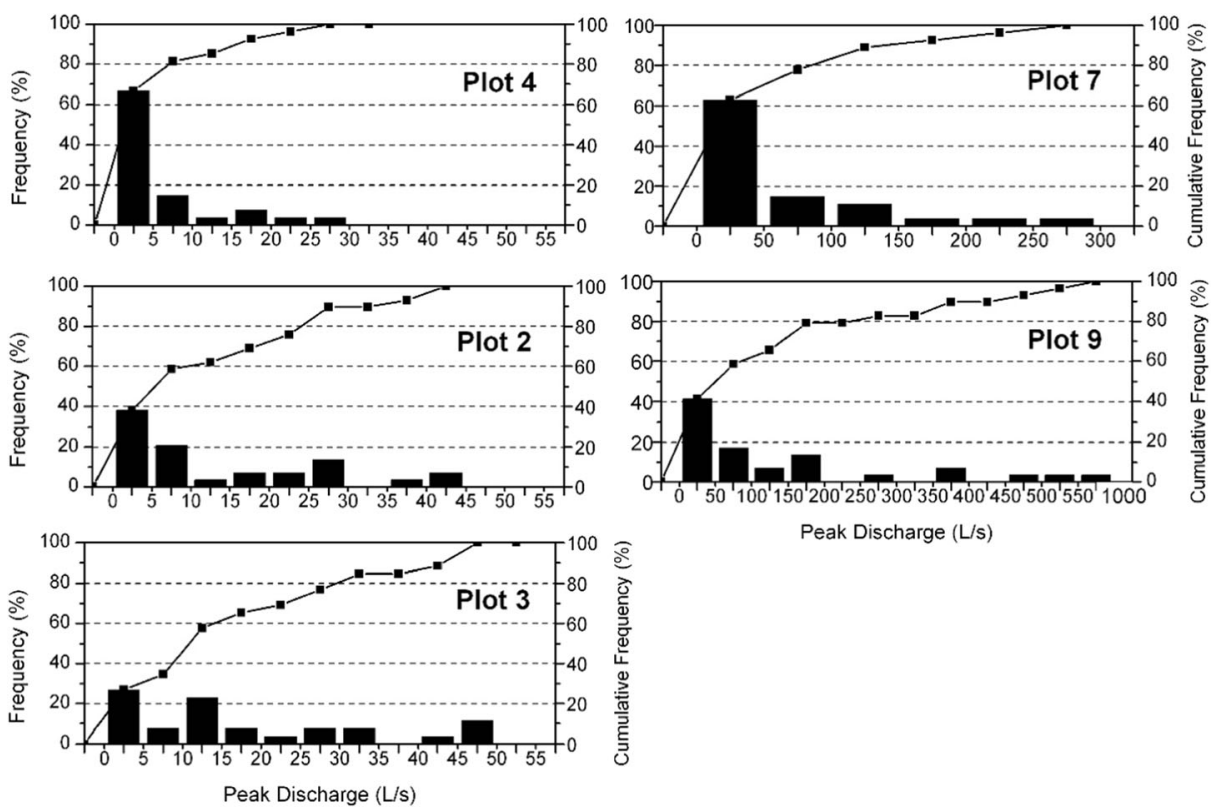

Peak Discharge (L/s)

Fig. 3 Histogram and cumulative frequency of the peak flow rate 

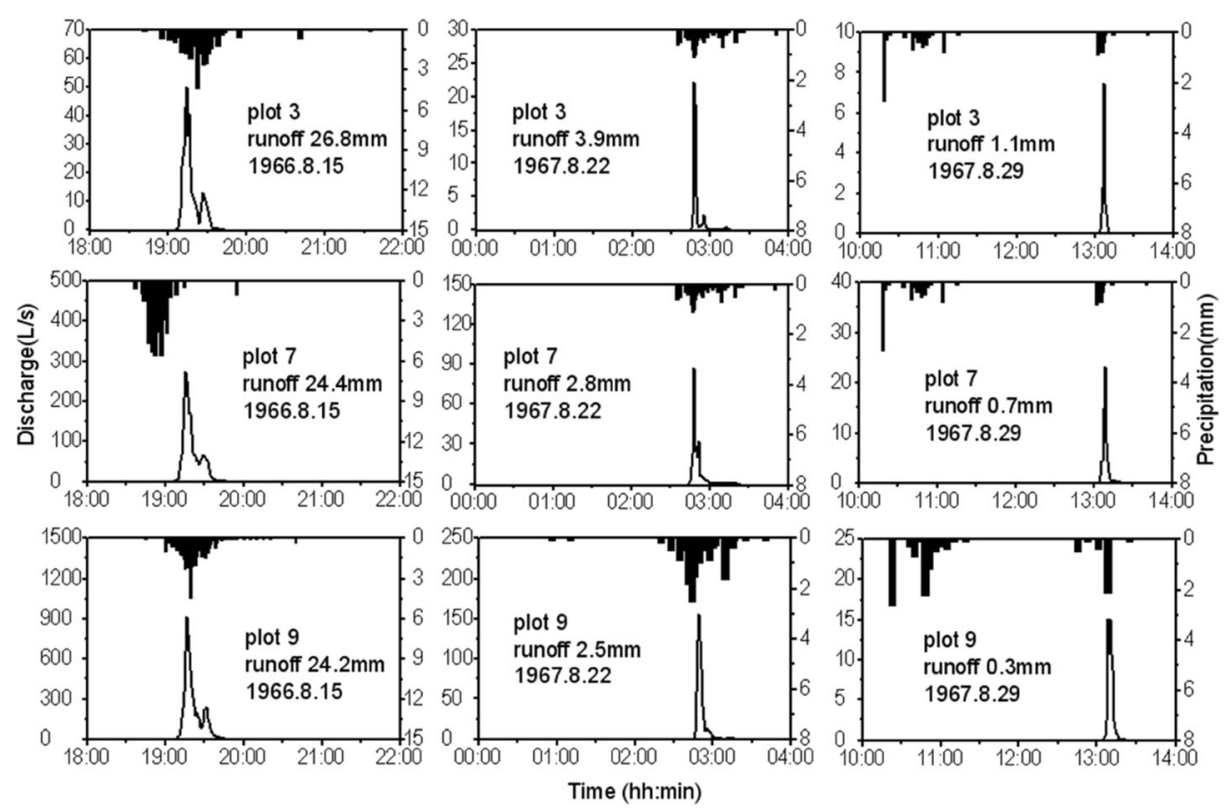

Fig. 4 Flow hydrographs for certain storms

increases when the area exceeds 1.72 ha. These results indicate that the peak flow equation in the CREAMS model provides better estimation accuracy for the plot scale but worse prediction for the watershed scale. In contrast, eq. (6) has worse prediction accuracy for the plot scale but more accurate estimation for the watershed scale. The MAEs for eq. (5) and (6) are similar to the $M E$ (Table 5).

\subsection{Development of New Equations}

The peak flow rate $\left(Q_{p}\right)$ was significantly correlated with plot area $(A)$, slope steepness $(S)$, runoff depth $(R)$, rainfall depth $(P)$ and maximum 30-min rainfall intensity $\left(I_{30}\right)$ at the 0.01 confidence level (Table 6). Thus, we conclude that the following relationship (eq. (9)) can be used to express the peak flow rate:

$$
Q_{p}=\mathrm{f}\left(A, R, P, I_{30}, S\right)
$$

Table 4 Watershed characteristics and peak flow rate

\begin{tabular}{|c|c|c|c|c|c|c|c|}
\hline $\begin{array}{l}\text { Watershed } \\
\text { name }\end{array}$ & Area $\left(\mathrm{hm}^{2}\right)$ & Length (km) & $\begin{array}{l}\text { Length-width } \\
\text { ratio }\end{array}$ & $\begin{array}{l}\mathrm{CS}^{*} \\
(\mathrm{~m} / \mathrm{km})\end{array}$ & $\begin{array}{l}\text { No. of } \\
\text { events }\end{array}$ & $\begin{array}{l}\text { Range of peak } \\
\text { flow }\left(\mathrm{m}^{3} / \mathrm{s}\right)\end{array}$ & $\begin{array}{l}\text { Mean peak } \\
\text { flow }\left(\mathrm{m}^{3} / \mathrm{s}\right)\end{array}$ \\
\hline Tuanshangou & 18 & 0.63 & 2.20 & 135.0 & 25 & $0.0024-10$ & 1.63 \\
\hline Shejiagou & 449 & 4.50 & 4.29 & 11.5 & 18 & $0.1280-90$ & 20.89 \\
\hline Xizhuang & 4900 & 8.54 & 1.49 & 15.0 & 22 & $0.4050-919$ & 122.17 \\
\hline Dujiagoucha & 9610 & 14.30 & 2.13 & 8.4 & 22 & $0.5470-939$ & 186.82 \\
\hline Caoping & 18,700 & 24.10 & 3.11 & 7.6 & 24 & $1.1900-1520$ & 227.52 \\
\hline
\end{tabular}

*Average Slope of the Main Channel 
Table $5 M E$ and errors of the two equations for plots and watersheds

\begin{tabular}{|c|c|c|c|c|c|c|c|}
\hline \multirow[t]{2}{*}{ No. } & \multirow[t]{2}{*}{ Area $\left(\mathrm{hm}^{2}\right)$} & \multirow[t]{2}{*}{ Events No. } & \multirow{2}{*}{$\begin{array}{l}\text { Mean peak } \\
\text { flow }\left(\mathrm{m}^{3} / \mathrm{s}\right)\end{array}$} & \multicolumn{2}{|l|}{$M E^{\dagger}$} & \multicolumn{2}{|l|}{$M A E^{\dagger}$} \\
\hline & & & & $\begin{array}{l}\text { Eq. in } \\
\text { CREAMS }\end{array}$ & $\begin{array}{l}\text { Eq. of } \\
\text { Fu' et al. }\end{array}$ & $\begin{array}{l}\text { Eq. in } \\
\text { CREAMS }\end{array}$ & $\begin{array}{l}\text { Eq. of } \\
\text { Fu' et al. }\end{array}$ \\
\hline Plot 4 & 0.03 & 36 & 0.005 & 0.554 & -4.267 & 0.003 & 0.013 \\
\hline Plot 2 & 0.06 & 34 & 0.012 & 0.738 & -2.198 & 0.005 & 0.020 \\
\hline Plot 3 & 0.09 & 32 & 0.015 & 0.771 & -2.571 & 0.005 & 0.025 \\
\hline Plot 7 & 0.49 & 26 & 0.063 & 0.776 & -0.240 & 0.021 & 0.061 \\
\hline Plot 9 & 1.72 & 21 & 0.205 & 0.689 & 0.828 & 0.079 & 0.071 \\
\hline Tuanshangou & 18 & 25 & 1.634 & 0.221 & 0.702 & 1.150 & 0.630 \\
\hline Shejiagou & 449 & 18 & 20.891 & -0.275 & 0.755 & 17.480 & 6.800 \\
\hline Xizhuang & 4900 & 22 & 122.173 & -0.347 & 0.885 & 113.580 & 38.290 \\
\hline Dujiagoucha & 9610 & 22 & 186.819 & -0.009 & 0.843 & 153.900 & 43.360 \\
\hline Caoping & 18,700 & 24 & 227.523 & -0.027 & 0.775 & 190.070 & 71.420 \\
\hline
\end{tabular}

Note: ${ }^{\dagger} M E$ is Nash and Sutcliffe model efficiency; $M A E$ is the mean absolute error

where $I_{30}$ is the maximum 30 -min rainfall intensity $(\mathrm{mm} / \mathrm{h})$, and $S$ is the slope steepness $(\mathrm{m} / \mathrm{m})$.

Dimensionless analyses were conducted based on the correlation analysis results. The runoff depth and $I_{30}$ were selected as the independent variables. According to Buckingham's $\pi$ theorem, the final result of the dimensional analysis can be expressed as the following function:

$$
\frac{Q_{p}}{R^{2} I_{30}}=\mathrm{f}\left(\frac{P}{R}, \frac{A}{R^{2}}, S\right)
$$

Based on eq. (10), a linear regression analysis was conducted according to the following equation:

$$
\log \left(\frac{Q_{p}}{R^{2} I_{30}}\right)=a_{1} \log \left(\frac{P}{R}\right)+a_{2} \log \left(\frac{A}{R^{2}}\right)+a_{3} \log \mathrm{S}+a_{4}+\varepsilon
$$

where $\mathrm{a}_{1}, \ldots, \mathrm{a}_{4}$ are regression coefficients.

In addition, the plot area, $I_{30}$ and runoff depth are straightforward to obtain and exert important effects on the peak flow rate. Thus, the linear regression analyses according to eq. (12) and (13) were also conducted.

$$
\begin{gathered}
\log \mathrm{Q}_{p}=a_{1} \log \mathrm{A}+a_{2} \log \mathrm{R}+a_{3}+\varepsilon \\
\log \mathrm{Q}_{p}=a_{4} \log \mathrm{A}+a_{5} \log \mathrm{I}_{30}+a_{6}+\varepsilon
\end{gathered}
$$

where $\mathrm{a}_{1}, \mathrm{a}_{2}, \ldots$, and $\mathrm{a}_{6}$ are regression coefficients.

Table 6 Pearson correlation coefficient between the peak flow and the other effect factors

\begin{tabular}{lllllll}
\hline & Drainage area & Slope & $\mathrm{L} / \mathrm{w}^{\dagger}$ & Runoff depth & Precipitation & I30* \\
\hline & $\mathrm{m}^{2}$ & $\mathrm{~m} / \mathrm{km}$ & $\mathrm{m} / \mathrm{m}$ & $\mathrm{mm}$ & $\mathrm{mm}$ & $\mathrm{mm} / \mathrm{h}$ \\
Pearson 's r & $0.400^{* *}$ & $0.240^{* *}$ & -0.140 & $0.447^{* *}$ & $0.387 * *$ & $0.459^{* *}$ \\
Sig. ** & 0.000 & 0.003 & 0.086 & 0.000 & 0.000 & 0.000 \\
\hline
\end{tabular}

** Significance at the 0.01 level. ${ }^{\dagger}$ The ratio of length to width of watershed. ${ }^{*}$ the maximum 30 min rainfall intensity 
The following regression results were obtained:

$$
\begin{gathered}
\log \left(\frac{Q_{p}}{R^{2} I_{30}}\right)=-0.846 \log \left(\frac{P}{R}\right)+1.035 \log \left(\frac{A}{R^{2}}\right)-0.899 \log \mathrm{S}-6.176 \quad \operatorname{adj} \mathrm{R}^{2}=0.974 \\
\log \mathrm{Q}_{p}=0.887 \log \mathrm{A}+0.846 \log \mathrm{R}-5.091 \quad \operatorname{adj} \mathrm{R}^{2}=0.951 \\
\log \mathrm{Q}_{p}=0.781 \log \mathrm{A}+1.486 \log \mathrm{I}_{30}-6.469 \quad \operatorname{adjR}^{2}=0.790
\end{gathered}
$$

The F-tests indicate that the eqs. (14), (15) and (16) were acceptable at the 0.001 confidence level. But, the adjusted $\mathrm{R}^{2}$ from eq. (16) was obviously lower than those from eq. (14) and (15). It shows that the combination of plot area and $I_{30}$ was not the best variables to predict the peak flow rate. The P-P plots of the standard residuals for eqs. (14) and (15) reveal that the

Fig. 5 P-P plots for standard residuals: (a) eq. (14) and (b) eq. (15)
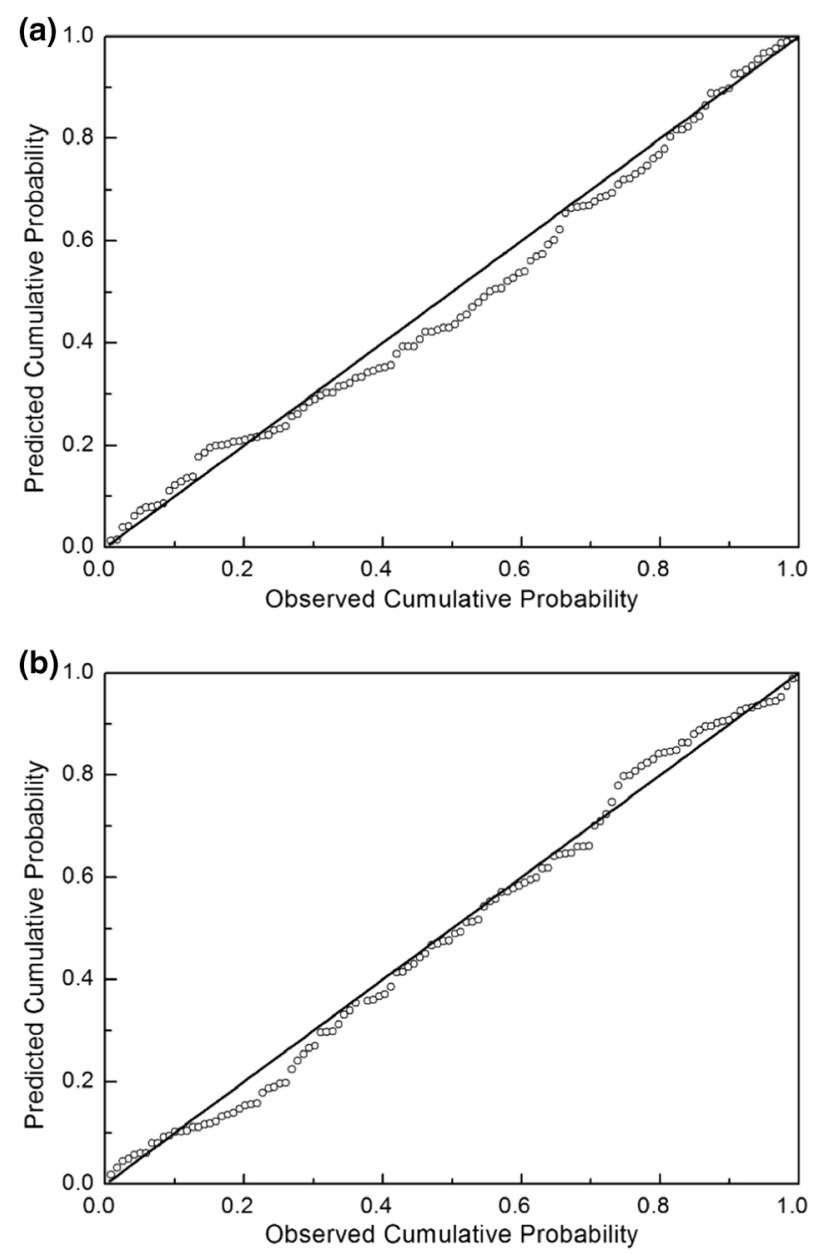
Table $7 M E$ and errors of the new equations compared with previously reported equations

\begin{tabular}{|c|c|c|c|c|c|c|c|c|c|c|}
\hline \multirow[t]{2}{*}{ No. } & \multirow{2}{*}{$\begin{array}{l}\text { Area } \\
\left(\mathrm{hm}^{2}\right)\end{array}$} & \multirow{2}{*}{$\begin{array}{l}\text { Events } \\
\text { No. }\end{array}$} & \multicolumn{4}{|l|}{$M E^{\dagger}$} & \multicolumn{4}{|l|}{$M A E^{\dagger}$} \\
\hline & & & $\begin{array}{l}\text { Eq. in } \\
\text { CREAMS }\end{array}$ & $\begin{array}{l}\text { Eq. of } \\
\text { Fu' et al. }\end{array}$ & Eq.(17) & Eq.(18) & $\begin{array}{l}\text { Eq. in } \\
\text { CREAMS }\end{array}$ & $\begin{array}{l}\text { Eq. of Fu' } \\
\text { et al. }\end{array}$ & Eq.(17) & Eq.(18) \\
\hline Plot 4 & 0.03 & 29 & 0.596 & -4.154 & 0.841 & 0.834 & 0.003 & 0.013 & 0.001 & 0.001 \\
\hline Plot 2 & 0.06 & 27 & 0.720 & -2.643 & 0.811 & 0.769 & 0.004 & 0.021 & 0.003 & 0.004 \\
\hline Plot 3 & 0.09 & 25 & 0.807 & -2.744 & 0.824 & 0.844 & 0.005 & 0.025 & 0.004 & 0.004 \\
\hline Plot 7 & 0.49 & 21 & 0.796 & -0.093 & 0.905 & 0.694 & 0.019 & 0.056 & 0.014 & 0.021 \\
\hline Plot 9 & 1.72 & 17 & 0.663 & 0.815 & 0.943 & 0.701 & 0.082 & 0.078 & 0.043 & 0.079 \\
\hline Total & & 119 & 0.790 & 0.798 & 0.960 & 0.807 & 0.018 & 0.034 & 0.011 & 0.017 \\
\hline
\end{tabular}

${ }^{\dagger} M E$ is Nash and Sutcliffe model efficiency; $M A E$ is the mean absolute error

residual was approximately normally distributed with a mean of zero (Fig. 5). No trend exists between peak flow and the residuals. Thus, eqs. (14) and (15) can be used to predict the peak flow rate. To simplify the equations, eqs. (14) and (15) can be rewritten as eqs. (17) and (18), respectively:

$$
\begin{gathered}
\text { Qp }=10^{-6.176} A^{1.035} R^{0.777} P^{-0.846} I_{30} S^{-0.899} \\
Q p=10^{-5.091} A^{0.887} R^{0.846}
\end{gathered}
$$

The MEs of eqs. (17) and (18) are clearly larger than those from Fu et al. (2008) and CREAMS (Table 7). MAEs of eqs. (17) and (18) are lower than those from $\mathrm{Fu}$ et al. (2008) and CREAMS. The peak flow rate predicted using eq. (17) and (18) tends to be evenly distributed on either side of the one-to-one line (Fig. 6). However, eq. (5) from $\mathrm{Fu}$ et al. (2008) and eq. (6) from the CREAMS model overestimate the peak flow rate, especially for low peak flow rates. These results indicate that eqs. (17) and (18) provide better prediction accuracy than those of Fu et al. (2008) and the CREAMS model for the plot scale.

Fig. 6 Measured versus predicted peak flow rates for the modeling dataset

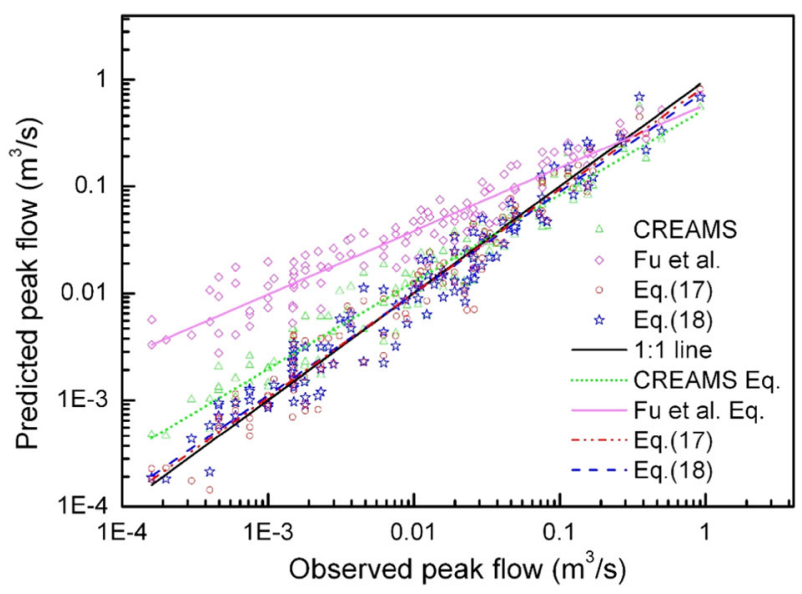


Fig. 7 Measured versus predicted peak flow rates for the validation dataset

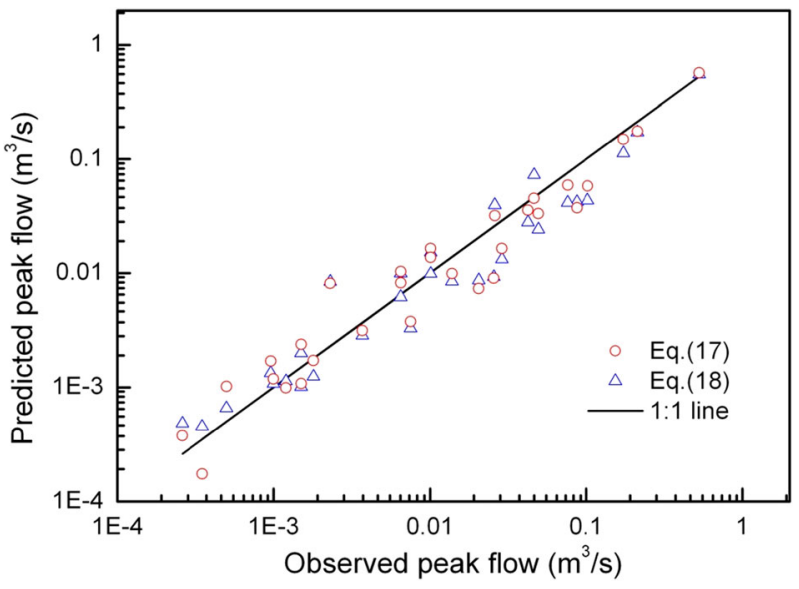

\subsection{Validation of the New Equations}

The 30 peak flow events that were not used to develop the equations were employed to validate them. Eqs. (17) and (18) exhibited high $M E$ values: 0.97 and 0.95 , respectively. The $M A E$ values were low (both equal to $0.01 \mathrm{l} / \mathrm{s}$ ). The predicted peak flow rates were evenly distributed on either side of the one-to-one line (Fig. 7). Thus, we can conclude that these two new equations predict the peak flow rate well.

\section{Conclusions}

The data for the runoff plots and watersheds were used to validate the peak flow rate equations of the CREAMS model and from Fu et al. (2008). The results indicated that the equation of Fu et al. (2008) was more suitable for predicting peak flow rates at the watershed scale and that the equation of the CREAMS model gave more accurate predictions at the plot scale. However, both overestimated the peak flow rate, particularly when the rate was low.

The new eqs. (17) and (18) were developed based on the results of dimensionless analysis and regression analysis. The variables of eq. (17) included drainage area, runoff depth, maximum 30-min rainfall intensity $(\mathrm{mm} / \mathrm{h})$ and slope steepness. Considering the data availability, a simpler eq. (18) was developed that only included drainage area and runoff depth. The results indicated that eqs. (17) and (18) provided good estimation accuracy with model efficiencies of 0.97 and 0.95 , respectively. The MAEs of eqs. (17) and (18) were low (both equal to 0.01 ).

The equations developed in this study represent an important supplement to the existing peak flow rate equations. These new equations will facilitate the design of soil conservation practices and the selection of flow-observation equipment with appropriate capacity for the plot scale.

Acknowledgements The research described in this paper was funded by National Key Research and Development Program of China (No. 2016YFC0501604), the National Natural Science Foundation of China (No. 41571259), the State Key Program of the National Natural Science Foundation of China (No. 41530858) and the CAS "Light of West China" Program. 
Open Access This article is distributed under the terms of the Creative Commons Attribution 4.0 International License (http://creativecommons.org/licenses/by/4.0/), which permits unrestricted use, distribution, and reproduction in any medium, provided you give appropriate credit to the original author(s) and the source, provide a link to the Creative Commons license, and indicate if changes were made.

\section{References}

Alexander GN (1972) Effect of catchment area on flood magnitude. J Hydrol 16:225-240

Ayalew TB, Krajewski WF, Mantilla R, Small SJ (2014) Exploring the effects of hillslope-channel link dynamics and excess rainfall properties on the scaling structure of peak-discharge. Adv Water Resour 64:9-20

Baver LD (1938) Ewald Wollny - a pioneer in soil and water conservation research. Soil Sci Soc Am Proc 3: $330-333$

Benson MA (1962) Factors influencing the occurrence of floods in a humid region of diverse terrain. US Geol Surv Water Supply Pap 1580-B:1-64

Benson MA (1964) Factors affecting the occurrence of floods in the southwest. US Geol Surv Water Supply Pap 1580-D:1-72

Chow VT (1964) Handbook of applied hydrology. McGraw-Hill, New York

Creager WP, Justin JD, Hinds J (1944) Engineering for dams, vol 1. John Wiley and Sons, New York

Di Lazzaro M, Volpi E (2011) Effects of hillslope dynamics and network geometry on the scaling properties of the hydrologic response. Adv Water Resour 34:1496-1507

Fu S, Wei X, Zhang G (2008) Estimation of peak flows from small watersheds on the loess plateau of China. Hydrol Process 22:4233-4238

Goodrich DC, Lane LJ, Shillito RM, Miller SN, Syed KH, Woolhiser DA (1997) Linearity of basin response as a function of scale in a semiarid watershed. Water Resour Res 33:2951-2965

Gupta VK, Troutman BM, Dawdy DR (2007) Towards a nonlinear geophysical theory of floods in river networks: an overview of 20 years of progress. In: Tsonis AA, Elsner JB (eds) Nonlinear dynamics in geosciences. Springer, New York, pp 121-151

Gupta VK, Mantilla R, Troutman BM, Dawdy D, Krajewski WF (2010) Generalizing a nonlinear geophysical flood theory to medium-sized river networks. Geophys Res Lett 37:L11402

Li Y, Poesen J, Yang JC, Fu B. Zhang JH (2003) Evaluating gully erosion using ${ }^{137} \mathrm{C}_{\mathrm{s}}$ and ${ }^{210} \mathrm{P}_{\mathrm{b}} /{ }^{137} \mathrm{C}_{\mathrm{s}}$ ratio in a reservoir catchment. Soil Till Res 69: 107-115

Knisel WG (1980) CREAMS: a Field Scale Model for Chemicals, Runoff, and Erosion from Agricultural Management Systems. USDA, Conservation Research Report No. 26: Washington.

Murphey JB, Wallace DE, Lane LJ (1977) Geomorphic parameters predict hydrograph characteristics in the southwest. Water Resour Bull 13:25-38

Neitsch SL, Arnold JG, Kiniry JR, Williams JR (2005) Soil and Water assessment tool theoretical documentation. Grassland, Soil and Water Research Laboratory, Agricultural Research service

O'Connell P (1868) On the relation of the freshwater floods of rivers to the areas and physical features of their basins and on a method of classifying rivers and streams with reference to the magnitude of their floods. Minutesnnnn 27:204-217

Ogden FL, Dawdy DR (2003) Peak discharge scaling in small Hortonian watershed. J Hydrol Eng 8:64-73

Williams JR (1975). Sediment-yield prediction with universal equation using runoff energy factor. In Present and Prospective Technology for Predicting Sediment Yields and Sources, (Proceedings of the Sediment-Yield Workshop, USDA Sedimentation Laboratory, Oxford, Mississippi, November 28-30). 244-252 